\title{
Deepor Beel Wetland: Threats to Ecosystem Services, Their Importance to Dependent Communities and Possible Management Measures
}

\author{
Jekulin Lipi Saikia \\ Jamsetji Tata School of Disaster Studies, Tata Institute of Social Sciences, India
}

Copyright $\mathrm{C} 2019$ by authors, all rights reserved. Authors agree that this article remains permanently open access under the terms of the Creative Commons Attribution License 4.0 International License

\begin{abstract}
Deepor Beel, only Ramsar site, is located in south-west of Guwahati, Assam. The Deepor Beel is the only storm water storage basin for the entire Guwahati city besides having enormous environmental and biological importance. But wetland is deteriorating due to various anthropogenic factors. The restoration and conservation of the wetland became the need of the hour due to growing frequent flooding in the Guwahati city. The current uses and historical uses of the wetland by the local community are discussed by focusing on the practices of two indigenous communities who have been dependent on wetland for centuries. These communities are Karbi and Koibortra community. It discusses the reasons for the shift of two communities from indigenous practices. From two different community perspectives, ecosystem services to the local community and its linkages to poverty were discussed. The current state legislature for the conservation of the wetland and its implementation and drawbacks were discussed. This is the direct testimony of the members of the respective community who has been suffering due to degrading condition of the wetland. A framework has been developed to understand the current situation of the Deepor Beel, and its implication on ecosystem services and its possible responses were drafted in this paper.
\end{abstract}

Keywords Ecosystem Services, Indigenous Practices, Poverty, Disaster Risk Reduction

\section{Introduction}

Wetlands play a vital role in human well-being for economic growth, climate mitigation and adaptation. They support countless species of plants and animals which depend on wetland for their survival. The wetlands have the capacity to adapt to climate change by storing carbon and this will help the humanities and wildlife. Wetlands have the capacity to lock up carbon in above-and below-ground bio-mass of primary producers. But when natural vegetation of wetland is converted into agricultural or urban land, carbon is released into the atmosphere as carbon-dioxide, it exacerbating climate change [1]. The important benefit of wetland can be connected to achieve sustainable development goals (SDGs). Therefore, we should conserve the wetlands through the globally sustainable development goals (SDG) agreed by the United Nations in September 2015. Wetlands have a critical role to play in all the SDG especially those concerning water, climate, marine resources, and ecosystems. Conservation and wise-use of wetland will help to achieve ten SDGs among seventeen SDGs [2]. The wetlands provide daily essential food materials and nutrients for the poor in both rural and urban and provide economic sustainability for those such as agriculture, fisheries, timber and other building materials, herbal medicines etc. whose economic activities were dependent on wetland, thus scraping poverty, hunger, provide nutrition and livelihood stability. Wetland supply water to the region; stabilize local climate, particularly rainfall and temperature; purify, recharge and discharge ground water; retention of nutrients, sediments, pollution and act as natural infrastructure by mitigating flood and drought, thus making the cities and human settlement safe and resilient. Women are predominantly responsible for food collection, agriculture, water collection and management. Therefore, recognizing the knowledge, roles and needs of women in management and conservation of wetland will empower women in decision-making and governance. With women empowerment, economic stability, food and nutrition can combat poverty and hunger. It also provides wildlife resources, energy resources such as peat and plant matter, transport, recreation and tourism opportunities. Thus, wetland will help to solve the problem of poverty, hunger, food security, nutrition, improved and promote sustainable 
agriculture, water and sanitation, sustainable economic growth, make cities and human settlement resilience to disasters, combat climate change, conserve and sustainable use of terrestrial ecosystem, reverse land degradation and halt biodiversity loss.

In the last few decades, frequency of natural disasters has increased and also it impacts on people, livelihood and environment. Climate change has increased the frequency of the nature or climate related hazards. Over $90 \%$ of the natural disasters are caused by water related hazards such as droughts, floods and storm surges. The losses and damages caused by disasters are the results of poor decisions which make hazards more severe and communities more vulnerable to disasters. Therefore, in order to have effective prevention, response and recovery, it became necessary to integrate environment, development and humankind. Wetlands act as natural infrastructure for water related hazards. Other than providing food and clean water, wetlands mitigate the impact of disasters, enhance coping capacities of the communities and make recovery sustainable [3]. Integrating wetland as traditional hard infrastructure for natural hazards will increase the resilience of the local community. However, the connection between wetland and disaster risk reduction are hardly understood and integrated into policies. But usually the ecosystem services of the wetland on which communities were dependent upon for food, economic well-being, protection and recovery is often ignored for disaster risk reduction. Often policy and decision makers lack integrating ecosystem for disaster risk reduction which can save lives, aid recovery and can build resilient community [4]. Therefore, conservation and wise-use of wetland is part of the Eco-DRR which helps in achieving sustainable management of the wetland for disaster risk reduction [3].

Globally, it is estimated that about $50 \%$ of the wetland have been lost due to various anthropogenic factor [5]. Wetland is associated with ecosystem loss which in turn makes places and people vulnerable to various natural hazards. This has an impact on community livelihood and biodiversity. Asia is the habitat Centre for a variety of animals and plants species. It is center of global mangroves found in Malaysia and Indonesia. Apart from this, 830,000 kilometers square were identified of peat bogs and swamps and 230 numbers of species were present in Asian wetlands. More than half of the Asian wetlands have been lost or under pressure and most of the wetlands were unrecognized [6]. India entered the Ramsar convention on $1^{\text {st }}$ February 1982 and a total of 26 sites are designated as Ramsar sites [7]. A large number of wetlands are temporary or man-made that were traditionally used and managed by local community [8]. In the North - Eastern part of India situated a state which is famous for one horn Rhino. The state is known as Assam, which is gifted with number of swampy areas and lakes which were locally known as "Beel (wetland)". The Beel in Assam are water-bodies for varying size were connected to Brahmaputra and Barak River and to its tributaries. There are about 1392 Beel in Assam, among which only 423 are registered. The Beel water covers a total area of about 1.0 lakh hectares which produces ten thousand tons of fishes per year. Beel are freshwater wetlands [9]. The origin of the Beel in Assam is related to channel that was cut-off from rivers, while some others have tectonic origin.

One of the Ramsar site situated in Assam is "Deepor Beel". It is the largest and the only Ramsar site in the Brahmaputra Valley which was included under Ramsar List in 2002 [10]. Deepor Beel is an abandoned channel of the Brahmaputra River which denotes a typical wetland comprising of core and a fringe area. The Deepor Beel is home of several endangered species such as Asiatic elephants, leopards, fishing cats, tiger, many migratory birds etc. Among the avifauna population in Deepor Beel, 102 species were found in the Beel, of which 55 are residential, 27 are locally migratory and 20 are migratory birds. The Beel have an effective self-purification capacity. Due to many anthropogenic factors in and around the Beel, its ecology and environment is being affected, impacting its biological diversity, ecosystem services and environmental quality [11].

Table 1. List of IUCN red - listed species found in Deepor Beel [12]

\begin{tabular}{|l|l|}
\hline COMMON NAME & \multicolumn{1}{|l|}{ SCIENTIFIC NAME } \\
\hline Mammals & Elephas maximus \\
\hline Asiatic elephant & Callosciurus pygerythrus \\
\hline Irriwaddy squirrel & Hylobates hoolock \\
\hline Hoolock gibbon & \multicolumn{2}{|l|}{} \\
\hline Birds & Pelecanus philippensis \\
\hline Spot-billed pelican & Aythya baeri \\
\hline Baers Pochard & Javanicus \\
\hline Lesser Adjutant stork & Haliaeetus leucogaster \\
\hline Pallas's Sea Eagle & Gyps tenuirostris \\
\hline Slender-billed vulture & Aythya nyroca \\
\hline Ferruginous Duck & Leptoptilos dubius \\
\hline Greater Adjutant stork &
\end{tabular}


Table 2. List of aquatic, shoreline, and forest vegetation and plants found in and around Deepor Beel

\begin{tabular}{|l|l|}
\hline Plants & SCIENTIFIC NAME \\
\hline COMMON NAME & Euryalea ferox \\
\hline Giant water lily & Vallisneria spiralis \\
\hline Tape grass & Hydrilla verticillate \\
\hline Hydrilla & Ipomoea reptans \\
\hline Swamp morning glory & Azolla pinnata \\
\hline Water velvet & Spirodela polyrhiza \\
\hline Giant duckweed & Eleocharis plantaginea \\
\hline Tuberous Indian plantain & Nymphaea albea \\
\hline Water lily & Sagittaria sagittifolia \\
\hline Arrowhead & Eichhornia crassipes \\
\hline Water hyacinth & Oryza sativa \\
\hline Rice & Eupatorium odoratum \\
\hline Floss flower & Achyranthes aspera \\
\hline Prickly chaff flower / Latjira & Cyperus esculentus \\
\hline Coco grass/ purple nut sedge & Phragmites karka \\
\hline Reed & Vitex negundo \\
\hline Chasta tree/ Indian privet & Murraya Koenigii \\
\hline Curry leaf plant & Saccharum Spontaneum \\
\hline Wild sugarcane & Pistia stratiotes \\
\hline Water Lettuce / tropical duckweed & Ottelia alismoides \\
\hline Duck lettuce & Lemna minor \\
\hline Duckweed & Ficus bengalensis \\
\hline Banyan tree & Bombax malabaricum \\
\hline Cotton tree & Terminalia belerica \\
\hline Belleric myrobalan & Tectona grandis \\
\hline Teak & \\
\hline
\end{tabular}
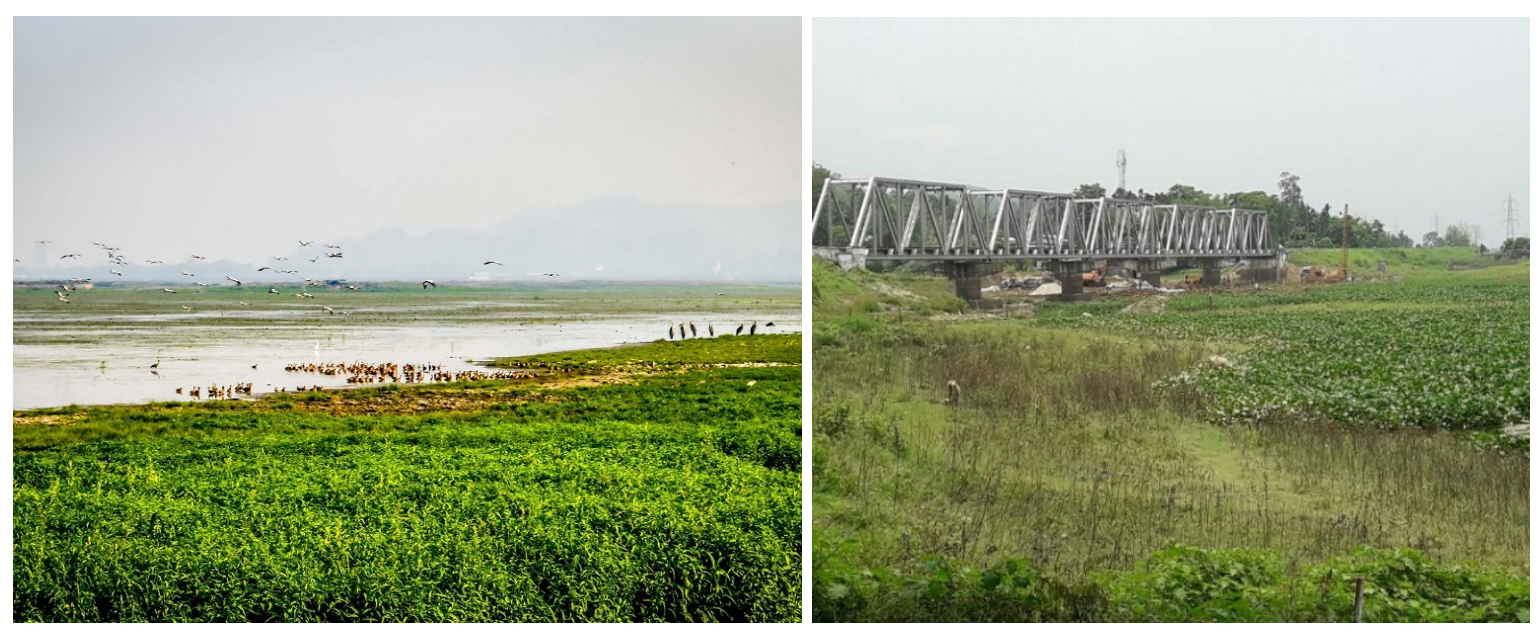

Figure 1. Extent of vegetation in Deepor Beel wetland 
The degradation of the Deepor Beel is due to the various anthropogenic factors such as waste disposal, illegal human settlement, railway line construction which have divided the wetland into two parts and growing croplands. Landscape development Index (LDI) indicates the impact of surrounding land-use pattern have increased on the wetland from 1989 to 2012 [13]. During this study, it was observed that wetland was converted into grassland which is the direct effect of various anthropogenic factors. Moreover, there is change in the catchment of the Deepor Beel caused by urbanization and deforestation. According to the current vulnerability assessment conducted by TERI of the Guwahati city, it is found that rapid unplanned urbanization and change in land-use pattern has put immense pressure on the natural landform and on the entire ecosystem of the city. Deepor Beel, which is an important water-body, has been degraded drastically by 14.1 percent between 1990-2002, thus increasing the flood hazard to the city as Beel act as storm water storage basin for the city [14]. The Guwahati city experienced flood every year due to encroachment and garbage dumping in the city drains and rivers like Bahini, Bharalu and Mora Bharalu have caused heavy flash floods. The natural wetlands which drain rainwater have reduced their capacity due to encroachment. Landslide is another hazard which occurs due to unplanned earth-cutting in the hills. The filling up part of Deepor Beel with garbage dumping has reduced its area of 40 square kilometers. The encroachment in Guwahati has set the stage for conflict on housing for those who does not have legal land tenure. While encroachment of the rich or high class was legitimized, the poor became the victims of eviction, which has led to the cycle of violence and counter violence [15].

Guwahati district is prone to frequent natural disasters such as floods, erosion, landslides, earthquake and cyclones. These disasters have caused serious disruption of the functioning of the society, causing widespread human, environment and material loss. The Guwahati district falls under Earthquake zone - "V". Soil erosion is a frequent phenomenon in Azara and Chandrapur revenue circle. The flood hazard in the district is due to dynamic monsoon rainfall and adding to it is various anthropogenic factors. The flood occurrence time is between May-August and cyclone from June-October which causes huge loss to human life, infrastructure, livestock and crops. The Brahmaputra valley has experienced major floods in 1986, 1988, 1996, 2000 and 2004. Disaster is the results of the poor decisions and actions which make the hazard more severe and communities more vulnerable. The Brahmaputra basin has the highest water yield in the world. With growing city population and development, the flood risk is being increasing because the natural drainage system has been blocked. The water storage capacity of the Deepor Beel has declined drastically. Therefore, there is a need to have better integration between environment, development and humanitarian actions for effective response, recover and preparedness.

Every year Guwahati faces water logging with only a few mm of rainfall. Deepor Beel helps to reduce flood and recharge the groundwater level but unfortunately it is day-by-day deteriorating due to overexploitation. This wetland has received little appreciation from the policy-makers in regard to their role in flood control, management of the ecological services and hydrological regime. New policies and sustainable management plan which is inclusive of local community need to be developed taking the advantage of the multiple values of the wetland. In order to maintain this natural infrastructure to disasters and to promote sustainable use, a clear understanding of its ecosystem services and threats which is impacting the wetland is required. The knowledge of anthropogenic factors affecting the ecosystem services of Deepor Beel, drivers of change and its impacts on rural livelihood is lacking in Deepor Beel. Therefore, through this paper, we synthesize the ecosystem services of the Beel focusing on two communities which were dependent on the Beel i.e. Karbi and Koibortra community.

\section{Methods}

\subsection{Study Area}

Deepor Beel is the only Ramsar site of Assam. Recognizing its international significance, Deepor Beel was added to Ramsar list as number 1207, due to its unique role in the social, ecological and cultural, social life to the population of Guwahati [16]. This number is given to the site in order to add them to the Ramsar list of international importance. This wetland is located between 26 degrees 6 minutes north and 26 degrees nine minutes north latitude; and 91 degrees 36 minutes east and 91 degrees 41 minutes east longitude. The average altitude is 50 to 57 meters above mean sea level. The wetland is located on the southern bank of Brahmaputra River and on the south-western fringe of the Guwahati city. It covers an area of more than 40 square kilometers. The Beel and its adjacent villages fall under Azara revenue circle of Kamrup-metro district. The national highway 37 is on the northern side of the Beel and touches its periphery at various places such as Dharapur, Azara etc. It is representative of the wetland found within the Burma Monsoon Forest Biogeography region. The wetland supplies a diverse group of goods and services to the local community and animal population. Deepor Beel along with Rani-Garbhanga reserved forests which is adjacent to the wetland adds a diverse wildlife habitation which increases its socio-economic importance of the wetland. The whole wetland was declared as a Ramsar Site in 2002 and within the Ramsar site was proposed as a wildlife sanctuary. It houses 80 to 120 Asiatic elephants [12]. The wetland serves as a major fish breeding and nursery ground and 
supplies fish stock to other nearby waterbodies. There are various invasive plant species which covers 50 percent of the wetland and several socioeconomically important species as well. Deepor Beel provides benefits both directly and indirectly for fourteen villages around the wetland. Almost 500 families of scheduled caste people are directly dependent on fishing and collection of herbaceous plants.

The wetland has a large congregation of Aquatic birds in Assam during winter and one of the largest sites of the migratory birds in India which supports a large number of IUCN red-listed species [17]. Beel provides livelihood for the local communities. The local communities traditionally collect the fodder for cattle, natural food such as vegetables, flowers and harvest fish and mollusc. Nymphaea nuts are harvested in the Beel for sale in the local markets and these constitute valuable natural crops. The seeds of giant water lily are annually leased by the revenue department. Deepor Beel directly supports many fishermen families from all the six villages. Fish yield of the Beel according to Government of Assam is at the rate of 245 kilogram per hectare [17]. Fish is the main source of livelihood and food for the rural people. Deepor Beel is the backbone of the local economy. The major source of revenue is collected by the government by selling fish and a seed of giant water lily. Deepor Beel was used as a mode of transportation by the local communities to supply vegetables to the Guwahati market. The wetland has a cultural connection with the communities. In the month of January, in Bihu Festival ${ }^{1}$, community fishing is practiced by neighboring villages using their different indigenous fishing methods. Other than providing foods and livelihoods for the villagers, Deepor Beel act as natural water infrastructure to the Guwahati city for floods, erosion, recharging groundwater, supplying and purifying the water.

The wetland is in a U-shaped valley bounded by steep highlands in the North and South side of the wetland. Basistha and Kalmani rivers and monsoon run-off is the major source of water for Deepor Beel. Geologic and tectonic history of the region, hydrology and channel dynamics of rivers and pattern of land use in the area is the reason for the origin and development of the wetland. The wetland receives surface runoff from the hills nearby, which is the reason for sedimentation of the Deepor Beel. The hills in the north and south side of the Beel are of Archaean age and the Beel and its fringe areas are made up of recent alluvium consisting of clay, silt, sand, and pebbles. In rainy season, the depth of the Beel increases up to four meters while in the dry season the depth drops to one meter. The spatial extent of Deepor Beel area has been decreasing due to sedimentation. 


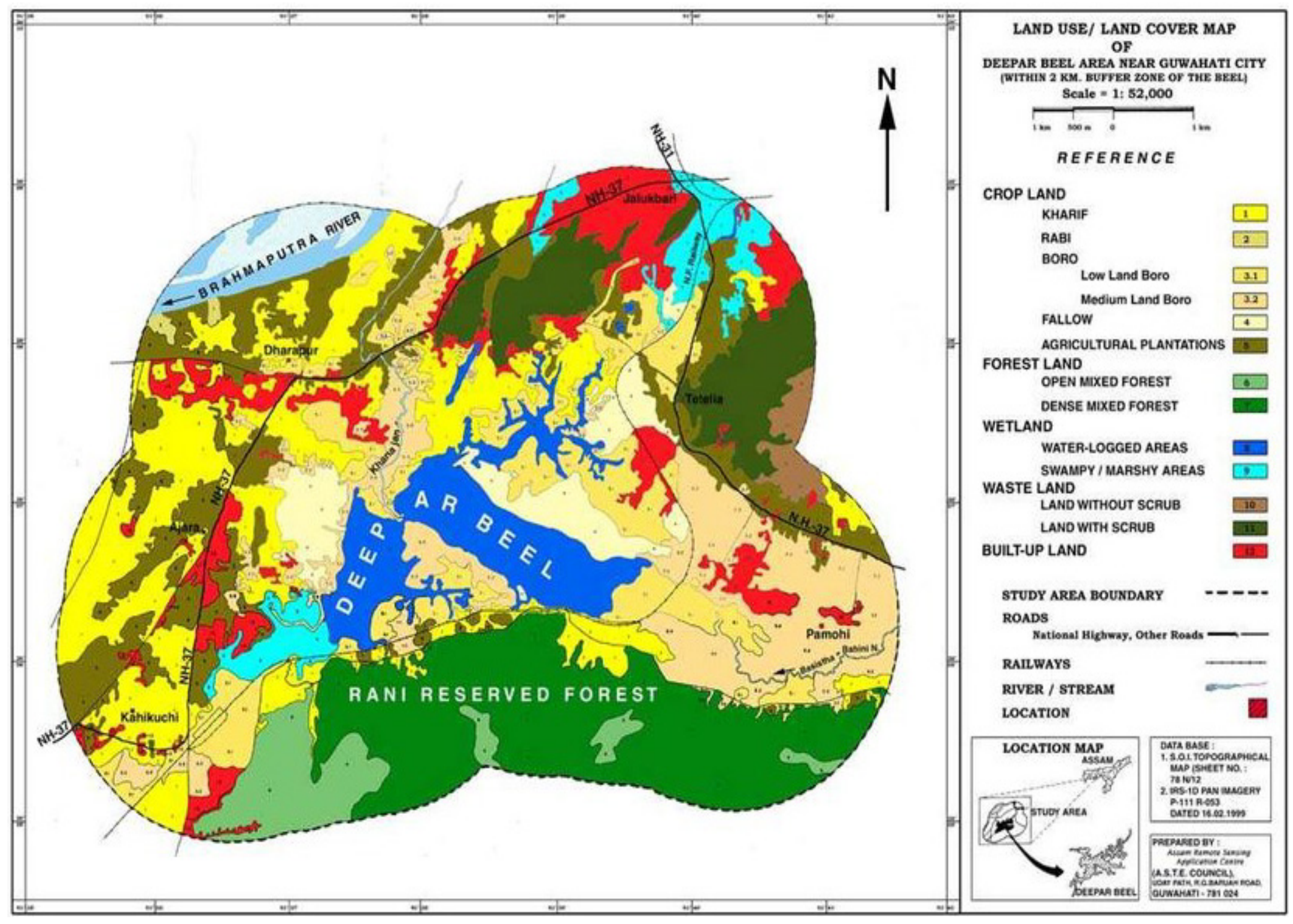

Figure 2. Deepor Beel 


\subsection{Ecosystem Services Provided by Deepor Beel}

The millennium ecosystem assessment has divided the ecosystem services as provisional, regulating, cultural and supporting services. All wetlands of the world have the potential of providing these services for the humankind. The wetland ecosystem services in developing countries are noted for direct benefit such as food, collection of firewood, fish and cropping. But in developed countries, indirect benefits are noted such as biodiversity and aesthetics.

The provisional services provided by Deepor Beel are food for both animals and human-beings. Karbi community cultivated paddy in the fringe area of the wetland. In the Karbi community, there were farmers who cultivate rice in the fringe areas of the wetland and were self-sustainable earlier. They also cultivated vegetables which were sold in the local market and Deepor Beel was used as a mode of transportation for their agricultural products. The community has a unique culture with their own type of rice cultivation, weaving, culture and dialect. For centuries, the Koibortra fishing community has been dependent on the wetland for their livelihood. The wetlands provide fodder for the animals. The elephants from the adjacent forest regularly visit the wetland for fodder including the plant species named Euryale ferox salish. The animals from the forests usually come to the wetland for water and for fodder. Lotus from the wetland were collected by the local community which was in abundance earlier and sold in the market during Durga Puja ${ }^{2}$ and supply it to the local temples. Deepor Beel provides significant regulator services. Wetlands contain characteristics vegetation of aquatic plants and play an important role in water purification, carbon sink, flood control and shoreline stability. It supplies fresh water to the city and recharge the groundwater. Deepor Beel is natural infrastructure which mitigates the physical impacts of natural hazards. Cultural services address recreational, educational, social relation and cultural value. On the day of BIHU, the annual festival of the local community- they do mass fishing which has cultural importance. The supporting services of the wetland are - It plays a significant role in increasing resilience to climate change and extreme weather events as well as ensuring climate change responses that would not lead to severe damage to the ecological character of wetland. Wetlands have the ability to store large quantities of carbon because they store dead wood and plant matter in the soil. The water logging condition prevents the materials from decomposing thus releasing $\mathrm{CO}_{2}$. Coastal marshes and mangroves capture on an average between six to eight tones of $\mathrm{CO}_{2}$ which is equivalent to per hectare per year. It is about two to four times greater than global rates observed in tropical forests [18]. Wetlands can provide multiple ecosystem services that play a vital role in climate adaptation. Flood water storage, storms water buffer, storage of water in drought prone area, filtration and processing of nonpoint source pollutants and sediment from runoff associated with more intense storm events, and habitat of numerous plant and animals' species and maintenance of biodiversity [19]. The Beel plays a vital role in maintaining a healthy ecosystem. Many local communities were dependent on wetland for livelihood. Its ecosystem enhances local resilience against disasters by providing fresh water and important products and by sustaining the lives and livelihood of local populations and biodiversity. 
Table 3. Major ecosystem services provided by or derived from Deepor Beel wetland

\begin{tabular}{|c|c|c|c|c|}
\hline $\begin{array}{l}\text { General Ecosystem } \\
\text { Services }\end{array}$ & \multicolumn{4}{|c|}{ Deepor Beel Ecosystem services } \\
\hline Services & Sub Category & & $\begin{array}{c}\text { Human } \\
\text { use }\end{array}$ & $\begin{array}{l}\text { Enhanced or } \\
\text { Degraded }\end{array}$ \\
\hline \multicolumn{5}{|c|}{ Provisioning Services } \\
\hline \multirow{5}{*}{ Food } & Crops & $\begin{array}{l}\text { In Karbi community, there are farmers who cultivate rice in the } \\
\text { fringe areas of the wetland. } \\
\text { The type of rice cultivated were- Bau, Boro and Hali paddy }\end{array}$ & & \\
\hline & Livestock & The grass was collected from the wetland as fodder to the cattle. & & \\
\hline & Fishing & $\begin{array}{c}\text { From centuries the Koibortra fishing community/SC community } \\
\text { has been dependent on the wetland for their livelihood }\end{array}$ & & $-/+$ \\
\hline & Aquaculture & SC community breed fish in the Deepor Beel for consumption & & $-/+$ \\
\hline & Wild plant & People collect Nymphaea nuts, Flowers, water lily seeds & & \\
\hline \multirow[t]{2}{*}{ Fibre } & Fishing & $\begin{array}{l}\text { SC community catch fish to sell in the local market thus people of } \\
\text { Guwahati receive fibre by consumption of fish } \\
\text { Fish yield of the Beel according to Government of Assam is at the } \\
\text { rate of } 245 \text { kilogram per hectare. }\end{array}$ & & $-/+$ \\
\hline & Wood Fuel & Local Community collect fuel wood for cooking & & \\
\hline Fresh Water & & $\begin{array}{c}\text { Deepor Beel is both economically and biologically important as } \\
\text { being the only major storm water storage basin for Guwahati city } \\
\text { It helps in Ground water recharge } \\
\text { It provides water for the wild animals from Rani-Garbhanga } \\
\text { reserved forests }\end{array}$ & & \\
\hline \multicolumn{5}{|c|}{ Regulating Services } \\
\hline Climate Regulation & $\begin{array}{l}\text { Regional and } \\
\text { Local }\end{array}$ & Provides good sink for greenhouse gases & & \\
\hline Water Regulation & $\begin{array}{l}\text { Regional and } \\
\text { Local }\end{array}$ & $\begin{array}{l}\text { Deepor Beel is the only major storm water storage basin for } \\
\text { Guwahati city } \\
\text { Regulates water quality, movement and volume } \\
\text { The main inlets of the Beel are the Mara-Bharalu and the Basistha } \\
\text { Bahini which carry the sewage as well as storm water from } \\
\text { Guwahati city }\end{array}$ & & $-/+$ \\
\hline $\begin{array}{l}\text { Natural hazard } \\
\text { regulation }\end{array}$ & Local & $\begin{array}{c}\text { Flood is the main disaster which Guwahati is experiencing every } \\
\text { year } \\
\text { Deepor Beel acts as natural infrastructure for water related } \\
\text { hazards }\end{array}$ & & \\
\hline \multicolumn{5}{|c|}{ Cultural Services } \\
\hline $\begin{array}{l}\text { Cultural heritage } \\
\text { value }\end{array}$ & Local & $\begin{array}{l}\text { On the day of BIHU, the annual festival of the local community- } \\
\text { they do mass fishing which has cultural importance. }\end{array}$ & & \\
\hline $\begin{array}{l}\text { Recreational and } \\
\text { Tourism }\end{array}$ & Local & $\begin{array}{l}\text { Wetlands are rich and unique ecosystems with many species that } \\
\text { rely on both the land and water for survival } \\
\text { Deepor Beel is home for almost } 232 \text { bird species belonging to } 42 \\
\text { families, the majority of which are migratory birds. } \\
\text { Fifteen endangered species of avian fauna were found in the } \\
\text { Deepor Beel }\end{array}$ & & \\
\hline Educational & $\begin{array}{l}\text { Regional and } \\
\text { Local }\end{array}$ & Vast biodiversity & & \\
\hline Social Relation & Local & $\begin{array}{l}\text { Wetland was used as mode of transport by Karbi Community to } \\
\text { transport their vegetables to sell in the market }\end{array}$ & & \\
\hline \multicolumn{5}{|c|}{ Supporting Services } \\
\hline Water Cycle & & Wetland helps in water cycle & N/A & N/A \\
\hline Transportation & Local & $\begin{array}{l}\text { It was being used as mode of transport by Karbi/ST community in } \\
\text { the southern side of the wetland }\end{array}$ & & \\
\hline
\end{tabular}

บ [ Means important (for human column) and increasing/enhanced (for enhanced or degraded column)]

[ Means declining importance (for human column) and decreasing (for enhanced or degraded column)]

$-/+$ [ Means mixed; some components increase while others decrease] 


\subsection{Data Sources}

The synthesis of the ecosystem services of Deepor Beel and threats to it is collected from both primary and secondary data source. For primary data, interview guide was used for conducting semi-structured interviews. For secondary data, journals, books, government documents, news articles have been used.

\subsection{DPSIR (Drivers- Pressure-State-Impact- Response) Framework}

At the first stage, Pressure-state-response model was developed by Organization for Economic Co-operation and Development in 1990. This model evaluated the environmental condition by identifying the cause of stress on the environment which is defined as Pressure. The condition of the environment is defined as State and how society response to the condition is defined as Response. But this model has limitations. It was too simple, narrow in its scope and it does not include natural factors into the pressure category. Therefore, this framework was modified by United Nations Commission on Sustainable Development. The new framework expanded the concept of pressure by incorporating the institutional, natural, social and economic factors of pressure. Another modification in the framework was done by incorporating the impacts of environmental change on the society. This will influence the policy so that every change is given equal amount of resources or attention [20]. Thus, a new framework was developed which is useful for decision-makers as well as for the public. DPSIR framework is a holistic way of organizing information about the state of environment. DPSIR is used for assessing the causes, consequences and responses to the environmental change.

drivers-pressure-state-impact-response framework, drivers are socio-economic and socio-cultural factors behind human activity and also the natural factors which can modify pressure on the environment. Pressures are stress which human activities put on the environment. State means the condition of the environment and impact refer to the consequences of the environmental condition on people, economy and ecosystem. Response means the responses of the society to the environmental condition [21].

With the increasing and diverse use of the Deepor Beel which is leading to degradation of ecosystem services, wildlife, landscape and biodiversity, it is necessary to develop a holistic policy to address all the problems and take into consideration all the user community. The natural environment is a complex system. Therefore, a holistic approach is needed to understand the connections that exist between elements of the wetland and to support policy makers in decision-making. In order to understand the complex wetland ecosystem and to develop a policy support, DPSIR framework is used. The DPSIR (Drivers-Pressure-State-Impact-Response) is a system-based approach which helps to understand the key relationships between humankind and environment and developed a relevant policy.

\section{DPSIR}

The data analysis is done on the basis of DPSIR framework where first drivers for change in ecosystem system services were identified and pressure on ecosystem services. The next stage is followed by state, then impact. Response is the last stage. Based on DPSIR, firstly, the mismanagement of the government for conservation and restoration of the ecosystem is studies followed by community dependent on wetland. The decline ecosystem services to the community and its implication on their livelihood, and increasing vulnerability is captured by using this framework. At the end of the study, few responses to the existing problems were suggested.

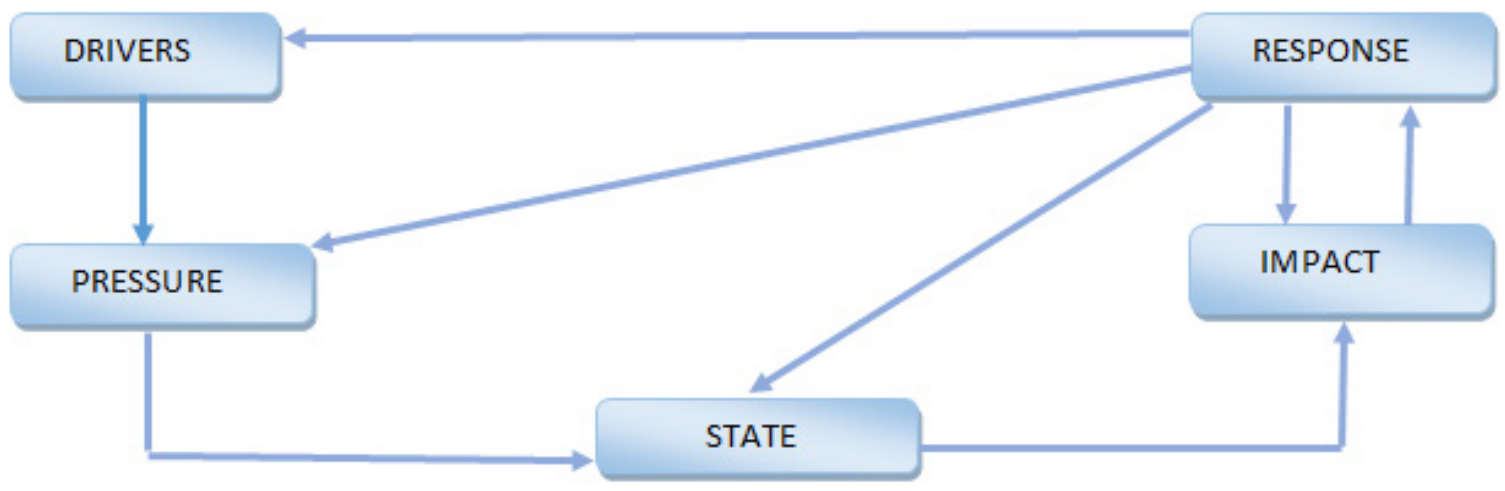

Figure 3. DPSIR (Drivers-pressure-state-impact-response) framework for Deepor Beel 


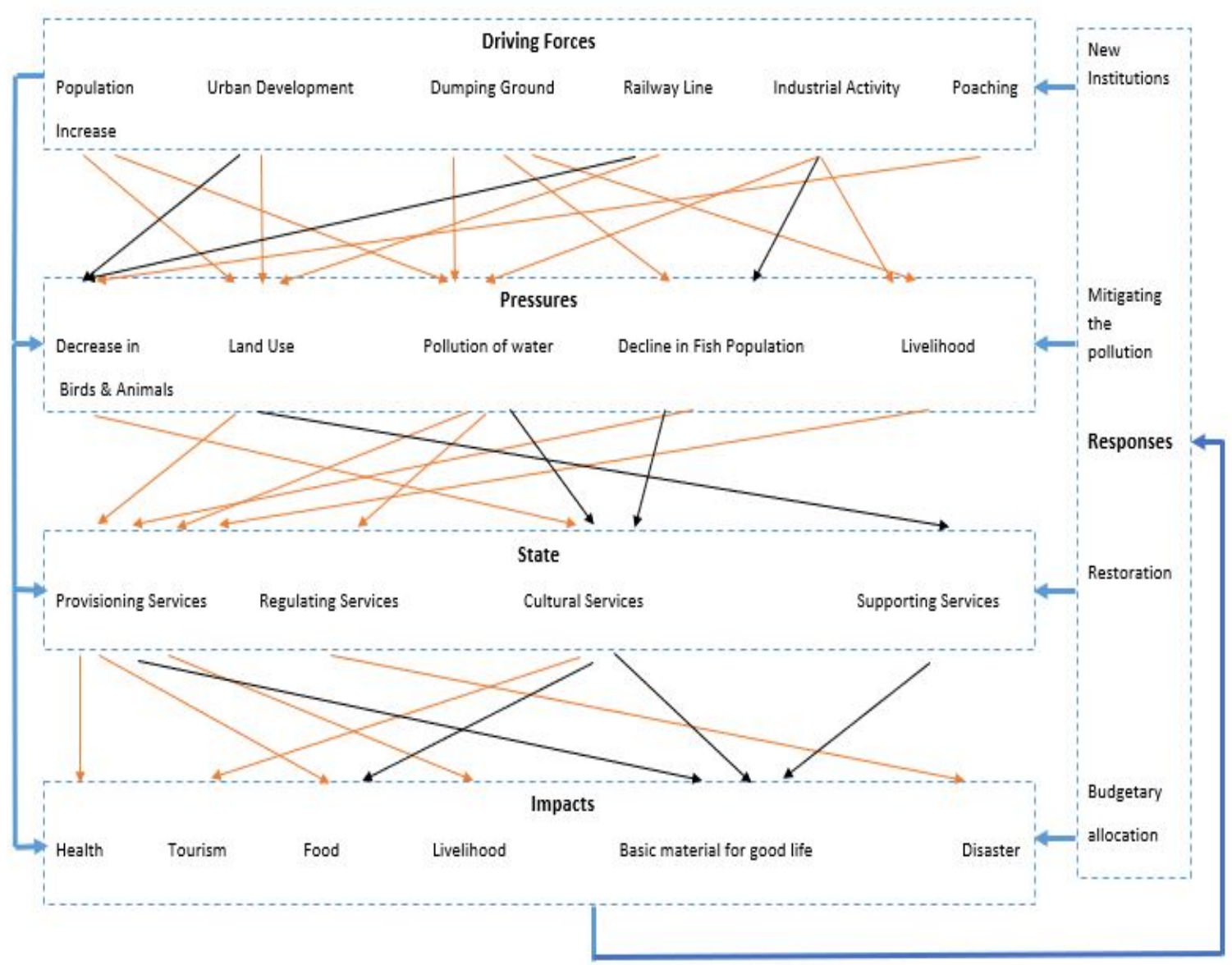

The line denotes direct link

The line denotes indirect link

Figure 4. Deepor Beel ecosystem services using DPSIR framework

\subsection{Regional Legislation}

The Ramsar Convention strategic plan along with SDGs should be integrated into planning and implementation efforts of regional legislation. Deepor Beel has different categories of users. Conflict for ownership or access to the Beel and its products or land between different individuals, sectors and administrations has therefore made it necessary to have regional legislation. It will help to have equitable distribution of resources, and to safeguard the wetland functions and values for the future. The regional legislation is developed on scientific basis which enhances the perception of wise-use and should be able to meet the needs, interest of local population, user groups, and all levels of government and non-governmental organization. The legislation is articulated, examined and compared for compatibility with wetland conservation and for sustainable use. In Guwahati, Assam - a regional legislation has been passed in 2008 in order to protect the wetlands situated in Guwahati. The legislation is as follows:

Guwahati Water Body (Preservation and Conservation) Act, 2008

The definition of water-body according to act - "Water body is the area or area of land where rain water accumulates and works as rain water reservoir and shall include wetland." This act comes under the jurisdiction of Guwahati Metropolitan Development Authority. It prohibits certain activities in the water-body such as construction in the water-body, dumping of solid waste, encroachment or filling up of water-body which may reduce the size of the water-body and can carry out only few activities such as fishing, aqua culture, conservation measures and flood control measures with prior permission from the authority. The competent authority or individual with permission from the authority can take up project of eco-tourism for better conservation and preservation of the 
water-body mentioned in the schedules I, II, III and IV ${ }^{3}$ of this act. The act doesn't mention about the wise-use of the resources nor does it focus on the indigenous practices of the community for conservation and preservation. It doesn't focus on protection of waterfowl population and plant species either; rather there is no mention about the maintenance of ecological character in the connection of sustainable development according to the fourth Ramsar Strategic Plan 2016-2014. Thus, it is concluded that regional act lacks certain aspects of conservation and wise-use of wetland.

\subsection{Pressure on Deepor Beel}

The Deepor Beel faces multiple kinds of pressure, dependent on the driving forces at play. The change in wetland ecosystem are the consequences of urban development, dumping ground in the eastern side of the wetland, construction of the railway line which divided the wetland into two parts, increase of population pressure on land, growth of industries in the fringe area of the wetland and the poaching of the migratory birds to sell in the local market. All this driving forces have become problematic to the ecosystem. Although legal institutions were passed in order to protect the wetland but nothing was implemented fully.

Decrease in the number of birds and animals and in fish population: Wetland have rich and unique ecosystems with many species that rely on both the land and water for survival. The migratory birds are affected which are feeding continuously on garbage on the eastern side of the wetland. The waste disposal is polluting the water. The fishes which are breeding in contaminated water are consumed by local community. Moreover, due to pollution, the vegetation is affected. In January of last year, 22 greater adjutant storks were found dead in Deepor Beel [22]. Greater adjutant storks are highly endangered and protected under Schedule IV of the Wildlife (Protection) Act, 1972.

Pollution of water: Water pollution is a major problem to the wetland. Water quality deteriorates due to pollutants such as fertilizer, pesticides used in agriculture, suspended solids, industry waste in and around wetland. This has impacted on the overall health of aquatic animals in the wetland systems. Presence of trace metals such as arsenic, cadmium, chromium, cobalt, copper, nickel, lead, manganese are found in water. In a study conducted by Guwahati University to determine the variation of the euphotic zone which was estimated by Secchi disk, it was found that transparency increases in wet months of June and August or might be the growth of aquatic vegetation. On the other hand, excessive growth of algae, presence of

3 Schedule I: SARUSALA BEEL

II: BORSOLA BEEL

III: SILSAKO BEEL

IV: DEEPOR BEEL suspended soil particles which reduces the transparency and photosynthesis in the deeper layers of water column by creating turbidity, reduces the growth of algae and water hyacinths leading to high productivity of fish [23].

Land Use: With increase in population, land use pattern has been changed. The agricultural land in the fringe area of the wetland has been sold out for the setting up of industries. The negative impact of this is the growing pollution which makes the soil infertile for agriculture. Due to contamination of the water, the crops die which create great loss to the farmers. Moreover, a growing number of factories are adding their waste water to the wetland. With the growing population, pressure has been put on land and the fringe area was converted as private land for construction of houses. These have huge impact on the ecosystem services of the wetland.

\subsection{State of the Deepor Beel}

The pressures discussed above contributed to the ecological change in the Deepor Beel. It is the combination of this pressure which leads to livelihood displacement of the local community. Although the extent and rate of the ecosystem changes from each of these pressures are not exactly known, it is clear that wetland is being degraded as a result. The unique biodiversity of the Beel has changed drastically and many endangered species has been lost. The turtle species which hatch eggs in the Beel is becoming extinct. This turtle enters through Brahmaputra then to Khanajan channel and then enter the wetland. This turtle community has stopped migrating to the wetland. The migratory birds such as adjutant stork have been killed due to consumption of food from the garbage. Also due to deforestation, the birds have stopped migrating to the wetland. The ecosystem services of the Beel have been eroded either directly or via interlinking of other wetland services. The ability to provide one service is dependent on the proper functioning of the other services. Hence, if one service is disrupted it will impact the others. Thus, it has negative impact on the local ecosystem as well. According to SDGs, wetlands provide multiple benefits for combating climate change, hunger, mitigating natural disasters, sustainable livelihood, land degradation etc. But due to pressures in Deepor Beel, it could not meet the SDGs for the region.

\subsection{Impact on Dependent Communities}

The impact of pressures on the indigenous practices of the two communities has been studied. The two communities are Karbi and Koibortra Community. In contemporary world, indigenous knowledge was gaining importance due to its potential of sustainability and environmental concerns which have been ignored long. Various dimensions of the indigenous knowledge were studies in abroad as well as in India for its both 
environmental and economic importance. Indigenous Knowledge of the community is the model-making of the functioning of the immediate vicinity [24]. Community creates the model through qualitative knowledge based on observations of the immediate vicinity. With observations and experience community learn to manipulate it, this model is closely integrated with religious belief and morals so that it co-evolves with knowledge, practice and beliefs.

\subsubsection{Karbi Community}

The $\mathrm{Karbi}^{4}$ community lived in the immediate villages of Deepor Beel such as Pamohi, Maghuwapara, Deuchutal, Mikirpara and Kalitapur. The Karbi community stays in the southern side of the wetland. The population of southern side of the Deepor Beel is approximately 1200 . The type of rice cultivated by them is- "Boro paddy" cultivation which starts from the month of December. "Bau paddy" cultivation which starts form the month of April and "Hali paddy" cultivation is cultivated simultaneously with Bau cultivation. "Bau paddy" cultivation is grown tall and it is resilience even to floods. When water of the wetland increases during monsoon season Bau paddy cultivation grow taller which doesn't affect the rice grains. Bau paddy cultivation was earlier done in the fringe area of the wetland. Hali paddy cultivation is done in the paddy field not on the wetland. From past decades they catch fishes from the wetland using indigenous tools and it is not done for commercial purpose. But since the past two decades, Karbi community have stopped growing rice and shifted their occupation as daily wage labors in the factory's setup in the precincts of the wetland. The paddy cultivation is affected due to water pollution, according to the community. The water in the wetland is getting polluted due to garbage dumping ground in the eastern side of the wetland along with the industries growing in the precincts of the wetland. The indigenous practice of the Karbi community is lost due to this.

Current occupation of the southern population is mainly businessmen, daily wage laborer and few in services. Only 20-22 households of Karbi population are farmers today. After Deepor Beel was declared as Ramsar Site, fishing was banned for commercial purpose but Karbi people catch fish for household consumption using indigenous tools. Other than pollution, another reason which affected the paddy cultivation is - as it was done in the fringe of the wetland, water dried up during the winter season. This fringe was converted into private land leading to establishment of many industries. It's only the core area which holds water throughout the year. Moreover, due to deforestation and development, the elephant food which was in abundance earlier was lost, due to these elephants enter into the local community paddy field spoiling thousands of hectares of cultivation. All these reasons led to the deterioration of the livelihood which was rice cultivation for the Karbi community thus leads to the loss of livelihood and poverty.

\subsubsection{Koibortra Community}

In the northern side of the wetland is the fishing community or Koibortra ${ }^{5}$ community. For centuries the Koibortra fishing community has been dependent on the wetland for their livelihood. There are 831 families of local fishermen from Koibortra community depending on Deepor Beel directly for their livelihood. They also collect flowers to supply in the local market and in the temples. According to indigenous practices of the Koibortra community, they have different fishing nets for twelve months of the year. In April, big fishing net is not used as this is the time for the fish to lay eggs. Just for survival, they catch fish in the outer part. The Kayoi and Puthi net is used to catch fish in the outer side of Deepor Beel as eggs were allowed to grow. In the month of January, as new born grow big as the size of two to three kilograms, Lani fishing net is used to catch big fish. For the sake of their livelihood, they have been conserving the Deepor Beel. But they are facing lot many difficulties after fishing was banned in the Deepor Beel without giving them alternate livelihood. Also due to contamination of water, fishes were dying. They have been working for conservation of Deepor Beel for decades. The name of the villages involving fishing are Keotpara, Natun basti, Nawa Para, Medhi Para, Matya, Barbari, Hirapara and Hatuapara.

\subsection{Interlinking of Wetland Ecosystem Services and Poverty}

In order to achieve positive conservation of the wetland and link it to development of the community we need to link poverty reduction with biodiversity conservation as per international developmental agenda. The Karbi and Koibortra community in the southern and northern side of Deepor Beel respectively are predominately rural with inadequate incomes that depend upon the local ecosystem for the survival. The rural fishing community and traditional subsistence farmers were at risk due to ecosystem degradation. Due to declining ecosystem services of the wetland on which the poor were dependent, they have been at increasing risk. The loss and damage of the wetland hampers the health and well-being of the individual and the local communities along with diminishing developmental goals.

5 Koibortra means Scheduled Caste community 


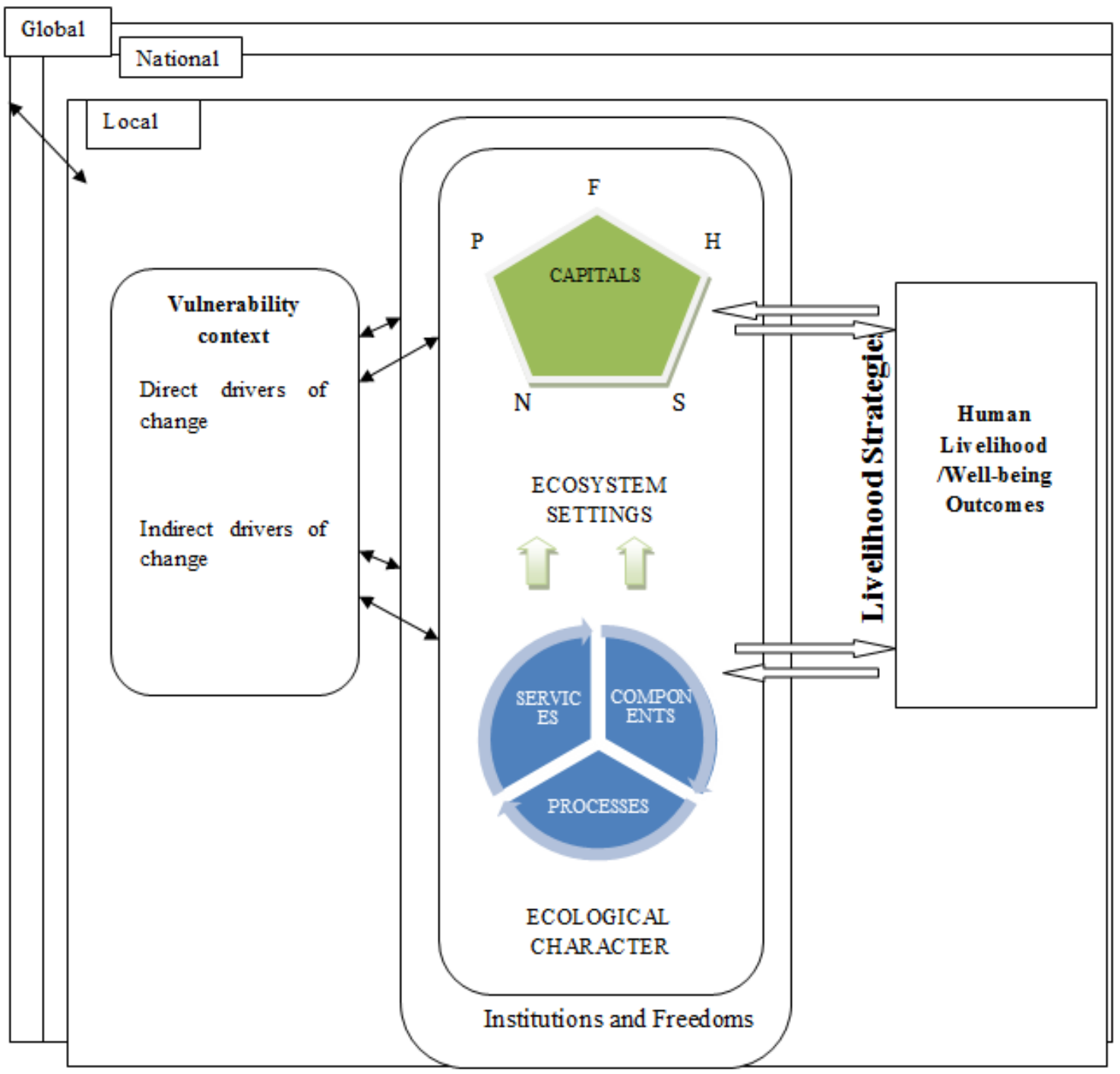

Figure 5. Framework for assessing wetland - livelihood interlinkages

This framework emphasizes wetland ecosystem to the local community which determines well-being of humankind as it provides water, protection from water-related hazards, protein, forest products, fodder, habitats and medicinal plants. Wetland is the place from which community derived their livelihood, and a place that enables them to bounce back better to disasters and enrich community lives. The wetland ecosystem services are part of natural capital so it is necessary to understand wetland ecosystem in order to rationalize the extent to which wetland can contribute to poverty reduction. The livelihood system was categorized as five sets of assets-natural, social, human, physical and financial [25].

The five sets of assets were linked with external environment which consists of direct and indirect drivers of change. The indirect driver of change includes economic, socio-political, culture, religion, technology, demographic and science. Direct drivers of change include change in land use pattern, external inputs, removal and introduction of new species, science and technology, climate change and natural, biological and physical drivers. With these drivers of change, internal environment becomes vulnerable.

In 1970s, the concept of vulnerability evolved out of social science which is starting point for risk reduction. Vulnerability addresses the sensitivity of the people and the community when exposed to stress or shocks and their social, cultural and economic abilities to cope with such damages. In order to explain the vulnerability context of the wetland-livelihood linkage framework, Egg model of sustainable development is used in the study which helps to understand the link between environment, society and economy. The vulnerability and sustainability depend upon the conditions of the surrounding environment as well as the condition of the inner sphere. The deterioration of the environmental sphere due to various direct and indirect factors increases the risk of disasters to the inner sphere. Thus, the ability to bounce back to the previous state is lost [26]. 


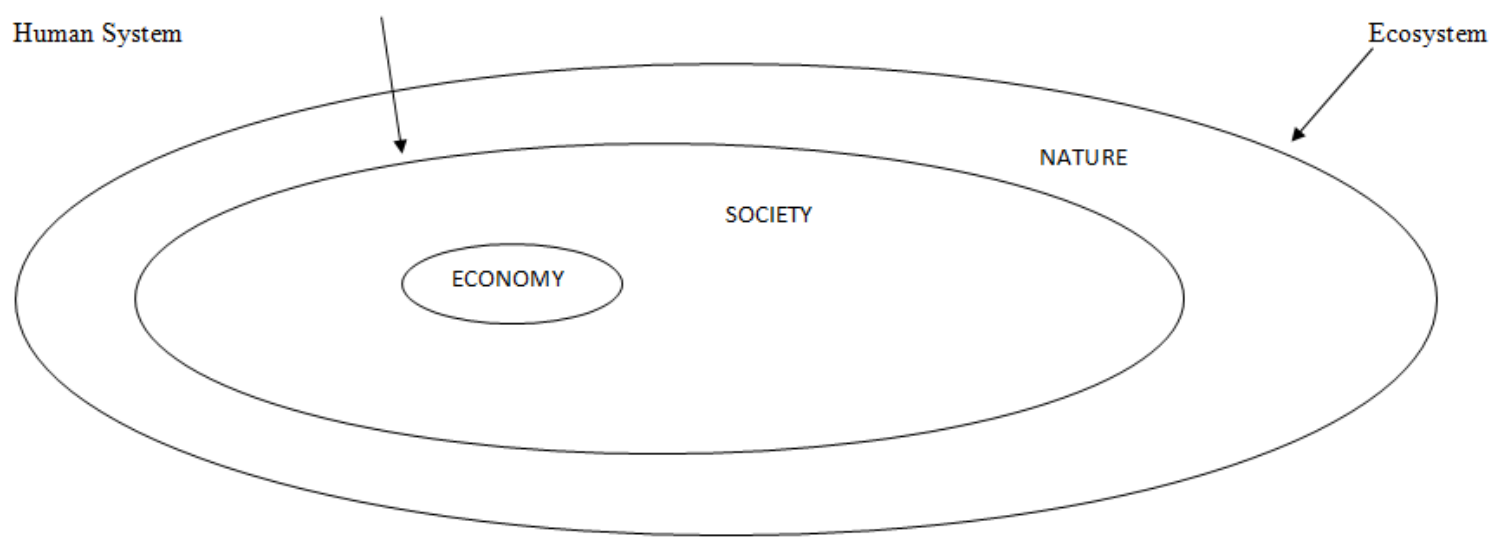

Figure 6. Linkages with external environment -vulnerability context

The degradation of environment through direct and indirect drivers increases the risk of disasters for the inner sphere which also led to poverty. The inner sphere loses its ability to return back to previous state post disaster. This inability to bounce back to negative stress and capacity of the system to function and maintain when in under stress is the key component of vulnerability. Vulnerability context is divided into direct drivers and indirect drivers. Major anthropogenic forces are dumping of city garbage which leads to water pollution, industrial waste, construction of railway line along with increase in demographic population and urban development had significant changes in the wetland ecological character of the Deepor Beel.

\subsubsection{Changes in Institutions and Freedoms}

The capacity of the community to revise or modify the institutions depends upon the freedom given to the community. The access to livelihood assets depends upon institutions framework including both formal and informal. Due to construction of railway line, wetland ecological character is disturbed. The increase in the level of water pollution leads to decline in subsistence agriculture and fishing. The majority of individuals' shifting to tourism or wage labors in industries leads to occupational displacement.

\subsubsection{Livelihood Strategies}

Increase in vulnerability contexts of the community, change in wetland settings, and in institutions and freedoms have affected livelihood strategies. Decline in livelihood of the fishermen due to banning of fishing .by forest department, dying of fishes, and decline in agriculture, decline in ecosystem services, and forest products due to water pollution is affecting the livelihood of the community.

\subsubsection{Human Livelihood Outcomes}

To attain livelihood outcome from wetland, three pre-conditions need to be achieved: internal sustainability, ecological sustainability and social sustainability. The direct and indirect drivers are impacting the livelihood outcomes which are highly detrimental to traditional fishermen and agrarian Karbi community. Change in ecological character adding to non-sustainable livelihood, thus leading to poverty. Increase in sedimentation leads to the shrinking of size of the wetland and decrease in storm water storage capacity. The after consequence of this is urban flooding as city drain water flows down to Deepor Beel.

\subsection{Responses}

Deepor Beel was declared as Wildlife Sanctuary in 2009 and forest department took possession in 2014. Forest Department looks after core area of the Beel which is 4.1 square kilometer which falls under Wildlife Protection Act, 1972. It also falls under the jurisdiction of Guwahati Water-body Act, 2008. A number of Management Action Plan has been made for Deepor Beel conservation but nothing has been implemented. The year 2002, ASTEC $^{6}$ have framed the management action plan for Deepor Beel, which focus on protection, watershed management, restoration, pollution control, community participation for socio-economic development, public awareness and monitoring and evaluation.

\section{Discussion}

DPSIR framework is able to capture the key relationship between society and environment which will help the policy-makers. This framework is too simplistic to capture other interaction but it acts as an effective analytical and communication tool. Our study is able to identify through DPSIR framework the ecosystem services provided by Deepor Beel, the major pressure that threats their

6 Assam Science Technology and Environment Council (ASTEC) 
continuous supply particularly the benefits that flow to the local community.

Major ecosystem services provided by Deepor Beel are fire wood, forest products; food such as fish, agricultural products; buffering against natural disasters; important plants for medicines; supports cultural fishing festival; Nymphaea nuts, and flowers especially lotus are harvested for sale in the local markets and these constitute valuable natural crops. However, during the last few decades, the wetland has experienced major changes due to anthropogenic changes, development pressures such as set-up of industries, garbage dumping, construction of railway line, deforestation, and pollution of water. Moreover, reclamation of wetland for residents, industries and other developments were prominent. Of the four major services from the ecosystem (provisional, regulatory, cultural and supporting), provisional and regulatory services were under the most pressure. Cultural and Supporting services were indirectly affected due to various anthropogenic factors. The deterioration of ecosystem services has impact on human well-being. The loss of regulatory and provisional services has the greatest impact on the livelihood of local community dependent on Deepor Beel. While cultural and supporting services are equally important for human well-being. The pressure of Deepor Beel is changing the supply of all the ecosystem services.

In order to have sustainable management of the wetland, a complete understanding of Deepor Beel wetland services is required. Few knowledge gaps have been identified here - In-depth understanding of the major threats to wetland needs to be understood. We need to identify which threat has the greatest impact and has changed the ecosystem services. The management and planning for protection of the wetland, an empirical study of the threats is necessary. There is a lack of wetland research and documents on Beel ecosystem services and its importance to human well-being for reduction of poverty. This lack of knowledge has restricted the management decision-making, as value of this wetland for poverty reduction are not known properly and connection of ecosystem services to human well-being are not clear. This information would help with sustainable resource management. The knowledge on value of different ecosystem services placed by user community, the quantity of services collected or used and how and for what purpose these services were being used. Such information will help to understand the characteristics connection between human well-being and ecosystem. Until then, the services of Deepor Beel for human well-being have been uncertain. We need to understand the nature of ecosystem services which benefits the local community. The understanding of different perspectives of socio-cultural, economic and ecological value is necessary for better understanding of wetland contribution. We need to identify and understand local community which is using and benefitting from the wetland more for effective conservation developmental initiative. It will help to identify on whom conservation initiative have to focused.

An enquiry of formal and informal institutions governing the wetland and its various outcomes needs to be understood to develop an integrated sustainable management plan. The understanding of informal institutions will reveal the prevalent indigenous practices governing the use of the wetland by the local community, which will promote informed decision-making. Majorly, there is a knowledge gap to identify the losers and beneficiaries of the ecosystem services. In the case of Deepor Beel, elites and government are beneficiaries and local communities are losers. The livelihood of local community was greatly impacted and has increased the risk of natural hazards. Due to this, community loses its resilience character. We need to understand the dynamics of political and social factors which are key determinants of the ability of the wetland to provide services for sustainable livelihood.

\section{Conclusions}

Our study has reviewed the ecosystem services of the Deepor Beel using the DPSIR framework. We find that the key services related to provincial and regulatory services are deteriorating although other services are equally important. The main threats to the wetland are water pollution, decline in fish population, land use pattern and decrease in the number of plant and animal species. There is a strong link between the main pressures on the wetland and its impact on provisional and regulatory services of the Beel. A series of knowledge are evident which affect the development of sustainable management. There is a need for a more detail knowledge for how and where the developmental pressure has affected the distribution of the ecosystem services, how Deepor Beel ecosystem services contribute to the human well-being, characterization of value of ecosystem services, reorganization of its economic and non-economic components, formal and informal institutions that can help to modify the ecosystem services benefits, and finally how these benefits were distributed among the communities.

\section{REFERENCES}

[1] Kai M.A Chan, M. R. (2006). Conservation Planning for Ecosystem Services. PLOS Biology Volume 4, Issue 11, 2138-2152.

[2] (July 2018). Scaling up wetland conservation, wise use and restoration to achieve the Sustainable Development Goals. RAMSAR CONVENTION ON WETLANDS.

[3] R. Kumar, S. T. (2017). Wetlands for Disaster Risk Reduction: Effective Choices for resilient communities. Switzerland: Ramsar Convention Secretariat. 
[4] Fabrice G. Renaud, K. S.-R. (2013). The Role of Ecosystems in Disaster Risk Reduction. Japan: United Nation University Press.

[5] Amy E. Daniels, G. S. (2008). Conversion or Conservation? Understanding Wetland Change in North-West Costa Rica. Ecological Society of America

[6] (2000). Map of wetlands of International Importance in Asia. Wetland International and World Bank; Wetlands in Asia.

[7] Ramsar Country Profile- India. (n.d.). Retrieved from Ramsar Convention: https://www.ramsar.org/wetland/india

[8] Sah, B. G. (1995). Inventory and Classification of Wetlands in India. Classification and Inventory of the World's Wetlands, 39-48.

[9] Kosygin, L. (2009). Wetlands of North-East India-Ecology, Aquatic Bioresources and Conservation. New Delhi: Akansha Publishing House.

[10] (2002). Deepor Beel Management Action Plan. ASTEC.

[11] Gohain, A. K. (1991). Studies on some water quality parameters of the Deepor Beel of Guwahati Area. Guwahati: Guwahati University.

[12] Subhro Mitra, A. N. (2014). Railroad impacts on wetland habitat GIS and modeling approach. Journal of Transport and Land Use, 15-28.

[13] Chitrini Mozumder, N. K. (2014). Ecosystem evaluation (1989-2012) of Ramsar wetland Deepor Beel using satellite-derived indices. Switzerland: Springer International Publishing.

[14] TERI. (2013). Risk Assessment and Review of Prevailing Laws, Standards, Policies and Programmes to Climate Proof Cities- Synthesis Report for Guwahati.

[15] Darshini Mahadevia, A. M. (2017). Ecology vs Housing and the Land Rights Movement in Guwahati. Economic \& Political Weekly.

[16] (2002). Deepor Beel Management Action Plan.

[17] (2008). Report on visit to Deepor Beel in Assam.

[18] Perceval, C., \& Cadmus, R. (2015, December 1). Wetlands: The Hidden Resource for Climate Mitigation and Adaptation. Retrieved from Ramsar.org: https://www.rams ar.org/news/wetlands-the-hidden-resource-for-climate-miti gation-and-adaptation

[19] Wetlands and Climate Change: Considerations for Wetland Program Managers. (July, 2015).

[20] Riley, R. E. (2003). Socio-economic indicators and integrated coastal management. Ocean \& Coastal Management, 299-312.

[21] Kristensen, P. (2004). The DPSIR framework. European Environment Agency.

[22] Times, T. S. (2017, January 26). 22 endangered birds found dead in a Guwahati sanctuary. Guwahati, Assam, India.

[23] Gohain, A. K. (1991). Studies on some water quality parameters of the Deepor Beel of Guwahati area. Guwahati, Assam: Guwahati University.
[24] Madhav Gadgil, F. B. (1993). Indigenous Knowledge for Biodiversity Conservation. Springer on behalf of Royal Swedish Academy of Sciences.

[25] Ritesh Kumar, P. H. (2011). Assessing wetland ecosystem services and poverty interlinkages: a general framework and case study. Hydrological Sciences Journal, 1602-1621.

[26] Birkmann, J. (2006). Measuring vulnerability to natural hazards: Towards disaster resilient societies. United Nations University Press. 